\title{
The digital great leap forward mapping China's 21st century attempt to create a new growth model**
}

\author{
ÁGNES SZUNOMÁR ${ }^{1,2^{*}}$
}

\begin{abstract}
${ }^{1}$ Institute of World Economics, Centre for Economic and Regional Studies, Tóth Kálmán u. 4, H-1097, Budapest, Hungary

${ }^{2}$ Institute of International, Political, and Regional Sciences, Corvinus University of Budapest, Budapest, Hungary
\end{abstract}

(C) 2020 The Author(s)

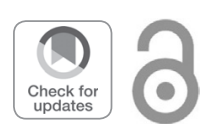

\begin{abstract}
The recent successes of the Chinese modernisation strategy are substantiated by an array of indicators showing an impressive improvement. Irrespective of China's current growth deceleration, these indicators suggest a highly effective implementation of an ambitious roadmap that can ultimately help China to catch up and achieve a global technological leadership. Still, some scholars point to deep structural deficiencies, and maintain that these indicators - however impressive they are - merely scratch the surface, while much deeper change is required in order to maintain economic growth. Therefore, the purpose of this paper (finalized before the ongoing COVID-19 crisis) is to contribute to this burgeoning literature - documenting the outcome and analysing the implications of China's efforts to embrace a new growth model - and analyse the chances of the Chinese digital great leap forward, that is the radical transformation of its prior modernisation trajectory. Drawing on a systematic review of the literature, the author maps, presents and analyses existing indicators quantifying China's progress in shifting to this new development trajectory, identifying also the gaps in the conventional measurement approaches. According to the findings of this paper, there are several easy-to-measure indicators, often used in international comparisons, that indeed confirm the optimistic scenario of China's development prospects in the near future. On the other hand, some hard-to-quantify factors, such as the localization of knowledge and the spreading of innovation, need to be also considered. These latter show a closer association with countries' development level as well as development potential. With regards to these latter particularities, China still has a long way to go.
\end{abstract}

*E-mail: szunomar.agnes@krtk.mta.hu

**This research was conducted in the framework of the project 'Non-European emerging-market multinational enterprises in East Central Europe' (K-120053) of the National Research, Development and Innovation Office of Hungary, as well as supported by the János Bolyai Research Fellowship of the Hungarian Academy of Sciences. 


\section{KEYWORDS}

China, modernisation strategy, digitalisation, artificial intelligence, innovative companies

\section{JEL CLASSIFICATION INDICES}

F63, 033, 038, N15

\section{INTRODUCTION AND RESEARCH QUESTIONS}

Since the early 2000s, international organizations' medium- and long-term forecasts have projected a global economic slowdown. There is a debate among leading economists about the role of various factors in explaining such slowdowns, as well as about further growth prospects (Adler et al. 2017; Baily - Manyika 2013; Remes et al. 2018).

Some economists (e.g., Eo - Morley 2018; Gordon 2014; Syverson 2017; Dufrénot Ghouzlane 2018) mentioned secular stagnation and a sharp slowdown in economic and productivity growth. Potential reasons for this slowdown are economic policy shortcomings, investment stagnation, political uncertainties, the protracted effects of the 2008 global crisis, measurement problems and demographic causes, as well as the ongoing structural transformations. However, when taking a closer look at Figure 1, it seems to be clear that the current (and expected future) unfavourable development of global growth performance can also be explained by the rather moderate growth of the BRIICS countries ${ }^{1}$ (Guillemette - Turner 2018). Nevertheless, the contribution of this group of countries - China and India in particular - to world GDP is steadily increasing: according to the OECD's forecast, China's share will be around $27 \%$ in the mid-2030s (Figure 2) finalized before the ongoing COVID-19 crisis.

China has maintained a double-digit GDP growth for decades during the period of the Chinese economic miracle, which lasted from the announcement of the 1978 Reform and

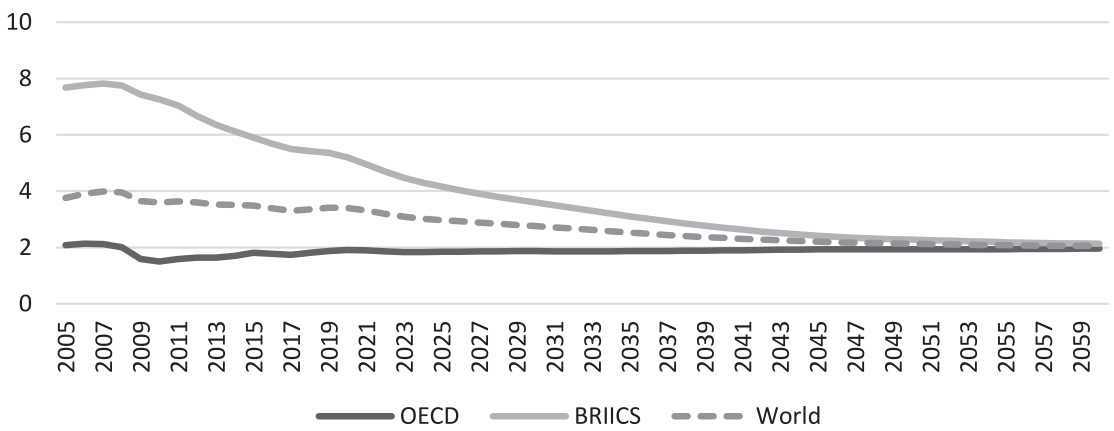

Figure 1. OECD forecast: real GDP growth (\%)

Source: Author's own compilation based on data collected from Guillemette -Turner (2018).

${ }^{1}$ Brazil, Russia, India, Indonesia, China, South Africa. 


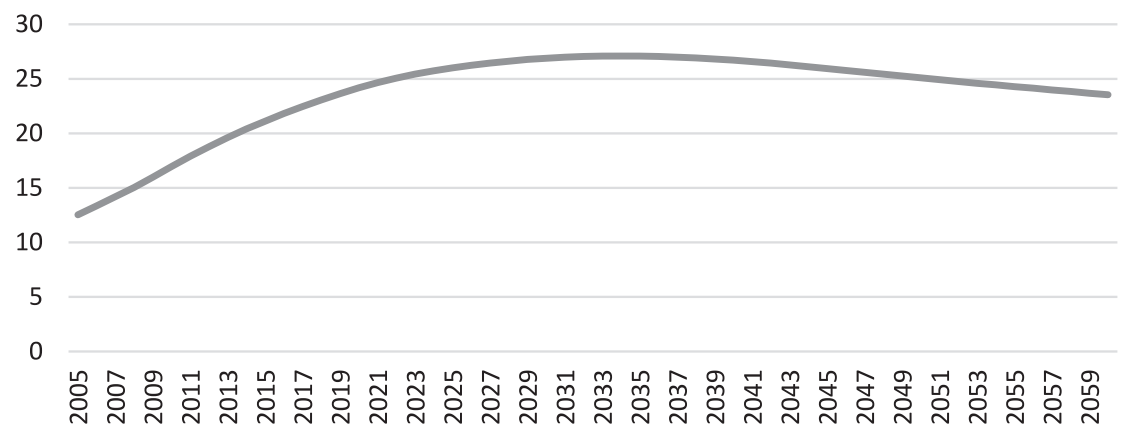

Figure 2. China's share of world GDP (\%)

Source: See Figure 1.

Opening Policy to 2008, the year of the global economic and financial crisis. The $10.4 \%$ increase measured in 2010 fell to $6.7 \%$ by 2016 , corresponding to a $3 \%$ deceleration rate (Tian 2019). The decline was unevenly distributed across sectors: the primary sector decreased from 4.3 to $3.3 \%$, the secondary sector from 12.7 to $6.1 \%$, and the tertiary sector from 9.7 to $7.8 \%$ (Xu 2019). Economists (e.g. OECD 2019a, 2019b; Xu 2019) agreed that among the primary demand components of growth, the decline in investment had the strongest effect, while consumption and exports also declined. Consequently, the Chinese government is no longer forecasting double-digit growth: growth of around 6\% will declaredly become the new normal, while structural transformation (i.e. changes in the economic sectors' and industries' share of GDP) has been continuously shaping and modernising the Chinese economy over the past decade and a half. To secure a long-term and sustainable growth, China has been strengthening the new drivers of economic growth and seeks to create the conditions for changing the modernisation trajectory by developing local innovation capacities, investing in education and R\&D, systematically developing emerging industries and technologies, and accelerating digital transformation in particular (Figure 3).

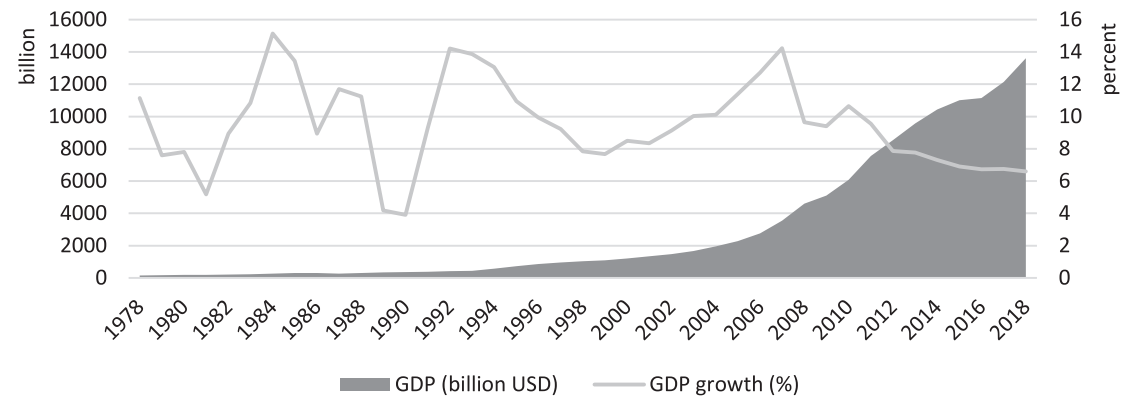

Figure 3. China's GDP volume and GDP growth rate, 1978-2018

Source: Author's own compilation based on data collected from World Bank Open Data. 
The effectiveness of the Chinese modernisation strategy is substantiated by an array of indicators showing an impressive improvement. Irrespective of China's current growth deceleration, these indicators suggest a highly effective implementation of an ambitious roadmap that can ultimately help China to catch up and achieve a global technological leadership. By contrast, one can find deep structural deficiencies in the Chinese economy, implying that these indicators - however impressive they are - would merely scratch the surface, while much deeper change is required in order to maintain economic growth. Therefore, the purpose of this paper - finalized before the ongoing COVID-19 crisis - was to analyse the chances of the Chinese digital great leap forward, that is the radical transformation of its prior modernisation trajectory. I examine whether the systematic development of the emerging industries and technologies is suitable to accelerate China's economic growth and achieve the desired shift to the new modernisation trajectory.

Drawing on a systematic review of the literature, I map, present and analyse the existing indicators quantifying China's progress in its modernisation endeavour, such as the industrial and technological specialisation, sophistication of exports, reduction of technological dependence, innovation and digitalisation, as well as the international success of domestically owned innovative companies. I also analyse the digitisation-related aspects of the Chinese modernisation, including the "Made in China 2025" program as well as the role of the Chinese companies in digital transformation.

\section{MAPPING THE TRADITIONAL INDICATORS OF CHINA'S MODERNISATION EFFORTS}

Innovation is certainly one of the key drivers of economic growth (Fernandes et al. 2018; Xiong et al. 2020), especially for the developing countries trying to avoid the middle-income trap (Eichengreen et al. 2013; Jayasooriya 2017; Glave - Wagner 2019). Zhuang et al. (2012) also concluded that a continuous industrial development requires innovation, thus ensuring the transition from a low-cost to a high value-added economy, for which the favourable macroeconomic and market environment is just as important as incentives for innovation. In Japan and South Korea, for instance, when becoming high-income economies, the productivity growth was primarily driven by innovation and new technologies, while structural transformation was already carried out.

The Chinese economic miracle of the 80 s, 90 s and early 2000 s was driven mainly by the structural transformation, the redistribution of labour and capital, i.e. their transfer from lowproductivity to high-productivity sectors and/or from state-owned to privately-owned companies. While structural transformation - transforming the economy from export- and investment-driven to a domestic consumption-driven economy that is based more on the tertiary rather than the secondary sector - is still on the Chinese agenda to address economic challenges, innovation-driven development has become the new strategy to guide China's economic rise.

A broader measure of technological development and innovation used in the literature is the growth of total factor productivity (TFP). Eichengreen et al. (2013) explained about 85\% of growth slowdowns in countries they analysed by the decline in TFP growth rates, while decline in labour and/or capital played only a relatively minor role. Jitsuchon (2012) and Bulman et al. 
(2014) also found that the countries that successfully avoided the middle-income trap showed relatively high TFP growth, consequently. TFP-driven growth - rather than input-driven growth - could be one of the cornerstones to economic growth in the developing countries (Tho 2013).

The TFP data calculated - and collected up to 2017 - by the University of Groningen support the above conclusions, as Chinese TFP has indeed been growing steadily in recent decades (Figure 4). ${ }^{2}$ The Chinese TFP growth exceeded that of its competitors till 2010, when the pace of TFP growth started to slow down sharply in all countries. However, as far as the level of TFP is concerned, Figure 5 shows that despite this relatively rapid growth, catching up according to this metrics has not started yet: China still lags far behind both its US and East Asian competitors, although the latter - i.e. Japan and South Korea - have not caught up either.

However, lagging behind is not necessarily a disadvantage. Lin (2019), for example, emphasised the benefits of such backwardness by saying that due to the productivity gap China's economic as well as productivity growth potential remains significant. China is not yet at the technological forefront, therefore its productivity growth is generated by several other factors, not only by innovation efforts. The human capital accumulation, robotization, and adaptation of technologies developed elsewhere - even in the absence of independent innovations - will have a significant impact on China's productivity growth in the near future, according to Lin. Consequently, the targeted technology and industrial policy component of the modernisation shift, discussed in detail in the next chapter, have a distinctive role.

$R \& D$ expenditures, that have a strong effect on the TFP growth, are also significant elements based on the literature mapping the results of economic development: this variable is also mentioned in connection with and independently of the TFP (Figure 6). Although China's performance is still lagging behind, for example, Japan and South Korea, where R\&D spending

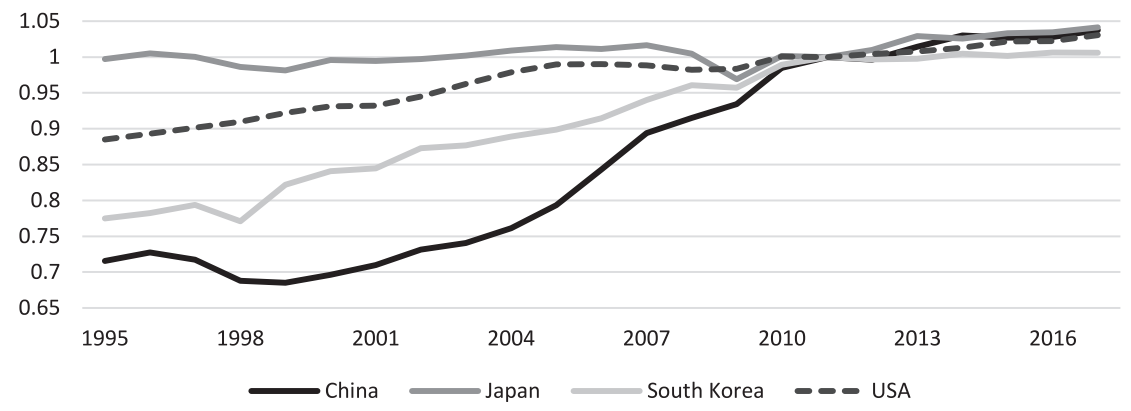

Figure 4. TFP growth in selected countries (at constant 2011 national prices) Source: Author's own compilation based on data collected from University of Groningen, Penn World Table (Feenstra et al. 2015).

${ }^{2}$ It should be noted, however, that the TFP database compiled by the University of Groningen is one of the most optimistic databases, especially when it comes to Chinese data, so this result is more of an assumption than a clear conclusion. 


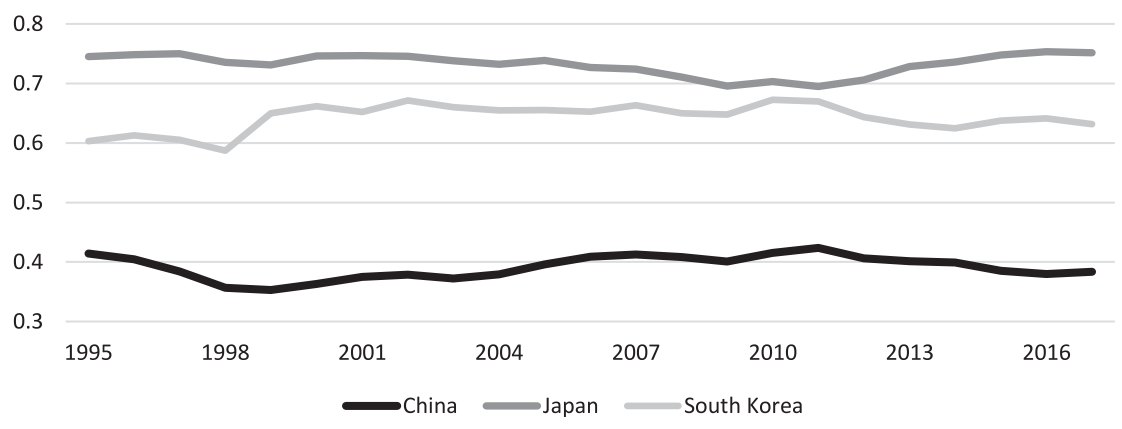

Figure 5. TFP levels in selected East Asian countries (USA = 1)

Source: See Figure 4.

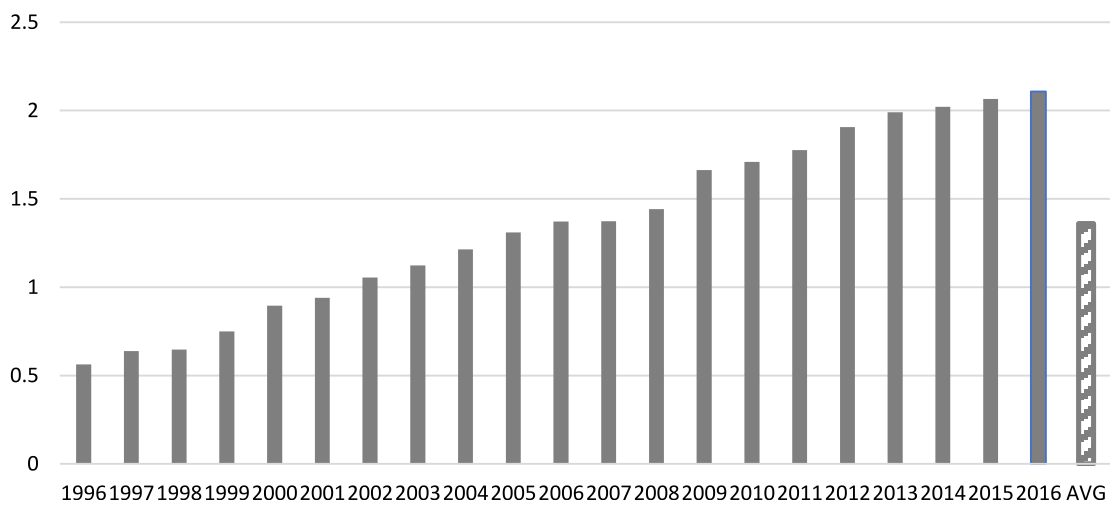

Figure 6. Chinese R\&D expenditure as a percentage of GDP, 1996-2016 Source: Author's own compilation based on World Bank Open Data.

is traditionally high, China's R\&D expenditure as a percentage of GDP is close to the levels of the European Union, Australia or Singapore.

Although differences among government policies and the domestic regulatory environment make it difficult to compare patent applications and cross-country subsidies, it is worth noting that in 2016, according to the World Intellectual Property Organization (WIPO), China's State Intellectual Property Office (SIPO) processed $42.8 \%$ of the global patent applications. With more than 1.3 million registrations, China has processed more than twice as many registrations as the United States, four times as many as Japan, and six times as many as South Korea. ${ }^{3}$

\footnotetext{
${ }^{3}$ It should be noted, however, that based on discussions with the Chinese scholars, the Chinese system is far from being perfect: one of the main reasons for many patent registrations is the registration of foreign patents, and the other is that doctoral students of technical disciplines can only obtain a $\mathrm{PhD}$ degree if they "invent" something - even if it is a useless or just plagiarized "invention".
} 


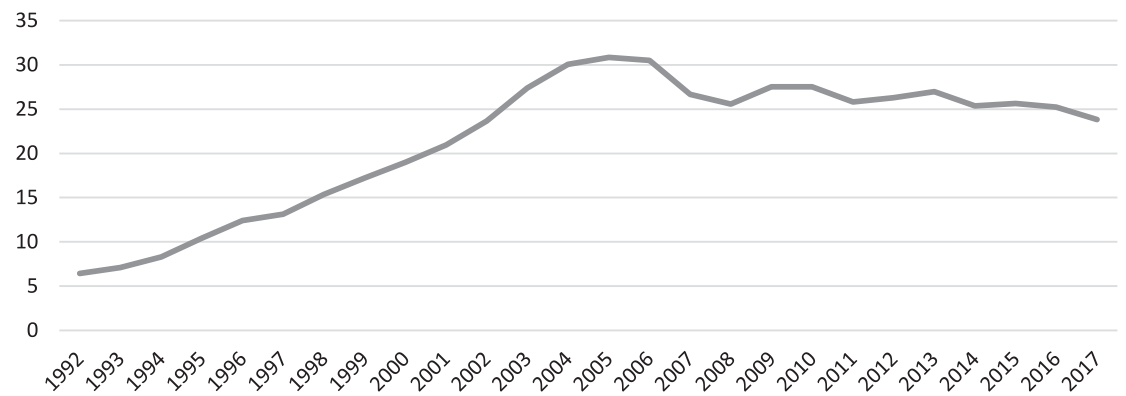

Figure 7. China's high-tech exports as a percentage of manufacturing exports, 1988-2017 Source: See Figure 6.

It is also worth examining the development of China's high-tech exports (Figure 7). According to Felipe et al. (2012), the more diversified a country's export and the more capable to produce and export sophisticated products, the more likely it is that this country will be able to develop, compared to those countries being successful in a single sector. A positive example is Korea, that became a successful exporter in several sectors, unlike, for example, the Philippines or Malaysia, that have only been successful in certain segments of electronics. Eichengreen et al. (2013) concluded that chances for a growth slowdown are lower among the countries producing high-tech products, while Felipe et al. (2012) also found that the countries that managed to avoid the middle-income trap countries are characterised by a relatively more diversified and sophisticated export basket (Figure 8).

In terms of trade structure, China remains competitive in the production of several low-cost and labour-intensive products, consequently these products represent a significant part of the Chinese exports. As a result - although China's major export products are electrical machinery and equipment - metals, furniture and various textile products continue to be a substantial item in China's export basket, making the export basket relatively diversified.

As far as the share of sophisticated products is concerned, according to the latest available data, nearly $24 \%$ of manufacturing exports came already from the exports of high-tech products. This ratio is well above the world average (16\%) and also exceeds that of the developed countries (it is around $13-14 \%$ in the USA, EU and Japan).

Figure 7 should be treated with caution, since Chinese domestic value added in high-tech industries is relatively low and, in many cases, the high-tech exports come from the foreignowned companies located in China (see Figure 9 for more details). A good example of this is a study by Dedrick et al. (2010) on some selected high-tech export products assembled in China, such as Apple's iPod. Based on the company balance sheet data, annual reports, industry databases, analytics and trade data, they calculated how the iPod value chain is structured, how much the built-in spare parts cost, where they are manufactured, what are the trade margins and the shipping cost per product, etc. It was found that within the retail price of the iPod, the assembly costs, along with the relating quality control costs, represent just over $1 \%$, and on a value-added basis, China's share is not more than $2-3 \%$. Although the country's share might be 


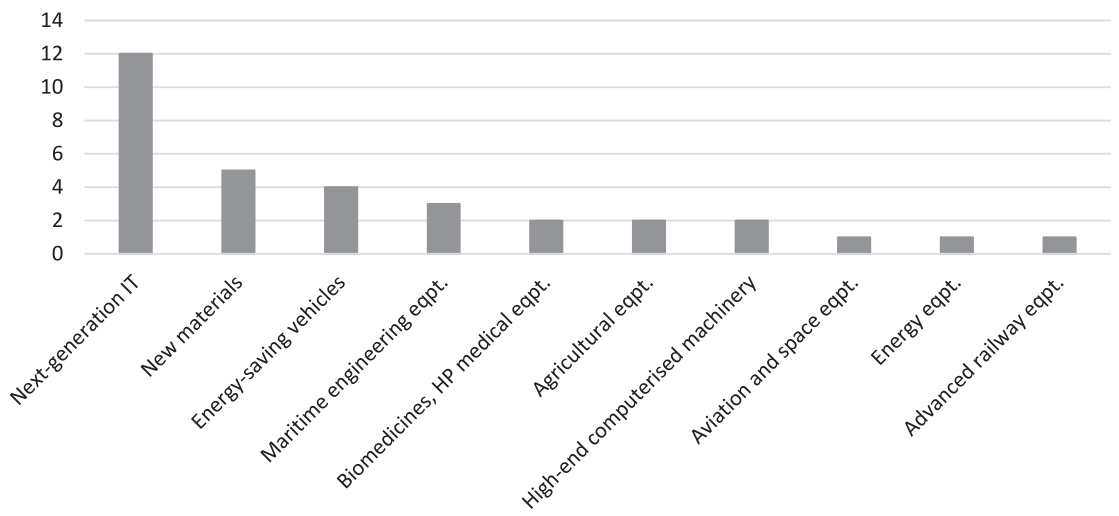

Figure 8. The number of national action and development plans in China, 2015-2018

Source: Author's own compilation based on data collected from MERICS (Zenglein - Holzmann 2019: 21).

somewhat more favourable now than it was in 2009 , but the local value added remains extremely low compared to the value of high-tech exports.

\section{CENTRALISED ECONOMIC PLANNING DELIVERING INNOVATION?}

For decades, China has been regarded as one of the main perpetrators of imitation and copying either through disrespect for intellectual property rights or through industrial espionage. While its capacity for high-volume and low-cost production has never been questioned, the conclusion was that the country's competitiveness in innovation is minimal. However, as mentioned above, China has also made substantial progress in the field of innovation in recent years and aims at becoming a new digital superpower. It is also known that the Chinese government promotes the concept of "independent innovation".

An important cornerstone of the process of becoming a digital superpower is the "Made in China 2025" (MiC25), a 10-year, grandiose industrial development plan that aims to shift from labour-intensive to knowledge-intensive manufacturing. ${ }^{4}$ It is the first step in a larger, 3-phase development plan that intends to transform China from a global assembly plant into an autonomous - i.e. that does not require foreign supply chains and technology - manufacturing power that uses innovative production technologies. The program focuses on improving the quality of the products made in China and encourages the creation of own brands through the development of stable production capabilities and state-of-the-art technologies. The first phase covers the 10-year period between 2015 and -2025 , where the primary goal for China is to

\footnotetext{
${ }^{4} \mathrm{MiC} 25$ was announced by the State Council of the People's Republic of China in May 2015 in response to the surge of the global reindustrialization and Germany's industry 4.0 strategy. The program was developed jointly by the National Development and Reform Commission (NDRC), the Ministry of Science and Technology (MOST) and the Ministry of Industry and Information Technology (MIIT).
} 


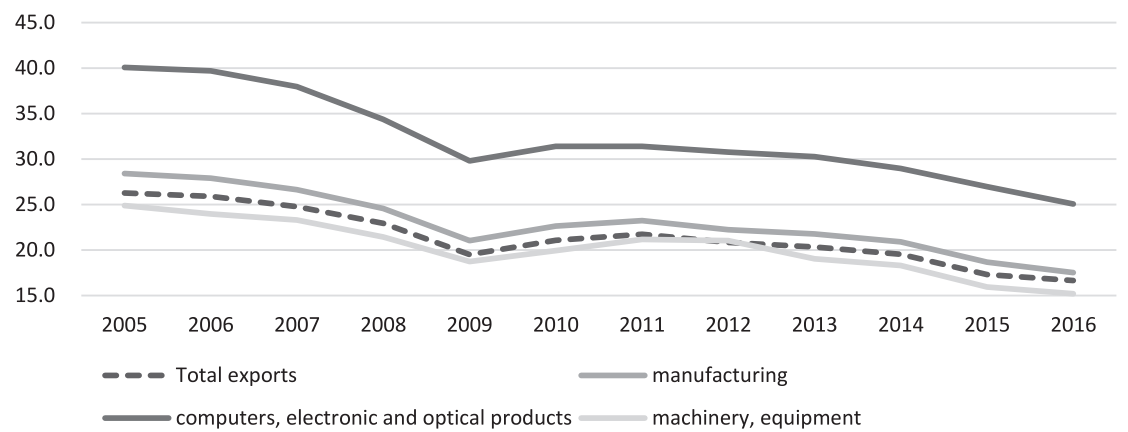

Figure 9. Percentage share of foreign value added in Chinese exports Source: Author's own compilation based on data collected from OECD TiVA database.

become one of the largest global manufacturing powers. The second phase is the period from 2026 to 2035, when China will catch up to the top manufacturing powers in terms of performance. By the end of the third phase, i.e. the period from 2036 to 2049, when the People's Republic of China is celebrating its 100th anniversary, China would like to be the world's leading manufacturing power ( $\mathrm{Li}$ 2018). The digital transition of MiC25 will be implemented in parallel, on three different - industrial, technology and regional - levels.

The first level is the development of selected strategic industries. ${ }^{5}$ MiC25 highlights and prioritizes 10 industries: next-generation information technology, high-end computerised machinery and robots, aviation and space equipment, maritime engineering equipment and hightech ships, advanced railway equipment, energy-saving and new energy vehicles, new materials, biomedicines and high-performance medical equipment, energy equipment, and agricultural equipment (Li 2018). The comprehensive industrial development plan is complemented and concretised by a number of industry and technology level development plans and scenarios (Figure 8).

Technology programs ${ }^{6}$ (second level) appear closely intertwined with the industry programs. The development of advanced industrial technologies (intelligent manufacturing) and artificial intelligence are among the flagship programmes in this regard, as these technologies are present in all industries, strongly influencing productivity (Szalavetz 2017, 2019). ${ }^{7}$ In 2017, the State Council announced a program called the "Next Generation Artificial Intelligence Development

\footnotetext{
${ }^{5}$ In this regard, MiC25 follows the development paths of Japan, South Korea, Singapore and Taiwan, as these East Asian countries have already successfully emerged from the trap of low-tech, labour-intensive manufacturing (assembly) with an industrial policy based on strategic sectors.

${ }^{6}$ One of these is the "Internet Plus" program announced in 2015 - on the personal initiative of Premier Li Keqiang. Actually, it is a modern five-year plan to integrate cloud computing, big data and Internet of Things with a variety of industries, from manufacturing and commerce to Iinternet banking, from government to healthcare or even agriculture. The program aims to connect China's growing economy, with the power of Internet services (Zhao 2019: 180).

${ }^{7}$ As regards the volume of developments, by the end of 2018, 530 industrial parks with intelligent manufacturing technology was established (Zenglein - Holzmann 2019). Most of them focus on processing big data, but new materials and cloud computing also play a prominent role (Woo 2017).
} 
Plan" (NGAIDP), highlighting that in addition to the international competition, national security challenges also require formulating artificial intelligence (AI) as a national strategy. According to the NGAIDP, the comprehensive development of AI - through theoretical modelling, technological innovations, software and hardware upgrades, etc. - will trigger a chain reaction that accelerates economic and social development. NGAIDP sets out a three-step policy for AI development: focussing on industry, technology and applications. For industry, it focuses primarily on machine learning, smart chips and cloud-based storage ${ }^{8}$; in the field of technology, the focus will be on the Internet of Things, Big Data, AI and intelligent manufacturing; while applications include geographic information system, smart grid, smart agriculture, information security and precision medicine. NGAIDP also assigns an important role to AI in university and post-graduate education: it mentions AI disciplines, AI majors, and even calls for the establishment of colleges specialising in AI (CISTP 2018).

The third level of the digital transition of MiC25 is the regional level. During the implementation of the program, the Chinese leadership also draws from previous experiences: even when the Reform and Opening was announced in 1978, the coherence between free market mechanisms and public planning policy was been tested in so-called special economic zones. Similarly, the Chinese leadership designated cities and priority areas to test the efficiency of MiC25. In addition to the designated cities (the first of which was Ningbo, a port city in southeast China), in line with the country-level strategy, major local governments created their own provincial and city-level technology development programs and roadmaps focussing on industries and AI (similar to the European 'smart specialisation strategy'), that also became an instrument for the local leaderships to compete for central resources.

For instance, Beijing is planning a 2 billion USD AI development park capable of accommodating 400 AI businesses, but Shanghai and Tianjin are also among the leading cities in terms of AI development. The former fishing village, Shenzhen, is now referred to as China's Silicon Valley. It is home to companies such as BYD, that is specialising in IT, cars and renewable energy, Huawei and ZTE, the two telecommunications giants, as well as Tencent, an Internet services provider, and the Beijing Genomics Institute specialising in genome sequencing. Shenzhen and its surroundings, the Pearl River Delta, will be transformed into a megapolis under the name Greater Bay Area, which becomes a key player in China's National Strategic Development Plan (Ketchum - Cheng 2018). But beyond that, Hangzhou (the capital of Zhejiang Province), the headquarter of the Alibaba Group, is also worth mentioning. The share of the service sector in Hangzhou was already above $60 \%$ in 2016, the ICT industries are also producing double-digit growth, while the implementation of the Internet Plus program mentioned above is also the most successful in this city, ahead of Beijing and Shanghai. Two kilometres from Hangzhou is a place known as "Dream Town," where the start-up Iinternet businesses are provided with free office space and infrastructure for at least three years. The initiative was launched in 2015 , with more than 7,000 companies working on more than 700 projects here in the first two years (Zhao 2019: 182).

\footnotetext{
${ }^{8}$ The program lists those AI industrial applications that needs to be developed independently (intelligent, connected vehicles, robotics, video surveillance systems, smart home products), the industrial equipment and logistics solutions integrating artificial intelligence required for their production and the infrastructure that supports these developments (5G systems, cybersecurity solutions).
} 
In line with the recent Chinese strategies, the program is not simply a set of one or more specific instructions, but rather a guideline capable of continuously adapting to emerging challenges, while maintaining the main objectives, i.e. modernising national technological capabilities and creating opportunities for technological leap. And, as demonstrated above, MiC25 is no longer a plan, as the implementation of the program has begun five years ago, with billions of dollars state funding. The amount of funding is, however, difficult to estimate accurately since besides direct allocations, companies can access grants through several other channels. For example, they can receive support in the form of tax incentives or from various development funds (provided by either state, provincial or state-owned companies/banks), ${ }^{9}$ but also through direct state funding of pilot and demonstration programs, priority projects or industrial and technology parks or special zones. The state provides indirect support through small and medium-sized enterprise financing programs and through central or provincial support for venture capital infusion (Zenglein - Holzmann 2019).

Although conditions were not necessarily ideal - the slowdown in economic growth has been a constant challenge, and the Sino - US trade war did not create favourable conditions either the implementation of the program gained momentum over the past few years. But, as Zenglein - Holzmann (2019) pointed out, the extent of the progress is difficult to measure due to the comprehensive and adaptive nature of MiC25.

The progress in the 10 priority industries listed above is far from balanced. China has already made spectacular progress in areas such as the development of 5G networks, high-speed railways and ultra-high-voltage electricity transmission systems, and the robotization of production. As for the latter, China not only outperforms the world average in many industries, but already uses at least as many robots as its competitors. ${ }^{10}$ China already uses more robots in the automotive industry than Japan or South Korea, while in the field of electronics it has more robots than the United States or Germany. In 2017, more than $40 \%$ of all newly installed robots went to China. ${ }^{11}$ The growth of robot production in China is even more striking. In 2012, 5,800 robots were produced, in 2017 already 131,000 units, nearly 30\% of which were produced by local companies (Cheng et al. 2019). The number of companies engaged in manufacturing of robots or robotics research is also growing rapidly: according to the State Administration for Industry and Commerce (SAIC), in the early 2000s, only a few hundred companies dealt with robots, but today this number is close to 7,000. This development is also justified by the increase in the number of robotics patents: SIPO, which deals with the registration of Chinese intellectual property rights, issued only 54 innovation patents in the field of robotics in 2000, compared to 319 in 2010 and 1,1145 in 2015.

The development of strategic industries based on domestic innovation is facilitated by the huge internal market: the Chinese government encourages the development of future technologies not only through financial support but also by artificially creating demand, including through favourable regulations or tax incentives (Shi-Kupfer - Ohlberg 2019).

\footnotetext{
${ }^{9}$ According to Zenglein - Holzmann (2019), in 2018, more than 1,800 public industrial investment funds operated in China with a total of 3,000 billion RMB.

${ }^{10}$ Quoted by Cheng et al. (2019) from the statistics of the International Federation of Robotics (IFR).

${ }^{11}$ Quoted by Dewan (2018) from the statistics of the IFR.
} 
Still, China's strategy to use innovation and digitalisation for the sake of the country's development faces a number of internal and external challenges. Conflicting goals and conflicts of interest among decision-makers cause tensions in the domestic arena, while increased state control over private enterprises and inefficient allocation of capital are also among the risk factors (Shi-Kupfer - Ohlberg 2019). As for external challenges, China will definitely remain dependent on foreign core technologies for some time, that can pose serious risks as illustrated by the US attacks against ZTE and later Huawei as a consequence of the Sino - US trade war. ZTE almost went bankrupt after the US threatened to ban the sale of microchips to the company, while Huawei was left almost without an operating system due to the US sanctions imposed on the company. In addition to the above, China is still dependent on the US for semiconductors. However, China has recognised the challenges of such dependencies and has been trying to take the appropriate steps to overcome them. China plans to halve imports of semiconductors in the coming years, eliminating it altogether in the long run, while Huawei has been developing its own operating system, called Harmony, for several years.

As can be seen from the above, digitalisation has become a top priority for Chinese leaders in just a few years. China is aiming to become world leader in many fields, such as AI, spending 150 billion USD on the industry by 2030, pioneered mainly by the private sector (Horowitz et al. 2018). It should be noted, however, that China's digital ambition goes beyond economic ambitions: effective governance, the control of companies and the population are also important aspects, for which the Chinese leadership has the right tools at its disposal. Here I just briefly refer to the "Social Credit System" that monitors the behaviour of individuals and companies, providing information about the trustworthiness, compliance with laws and legal violations. In addition to the economic and social use, AI can also be used for military purposes.

\section{WHO'S IN CHARGE: STATE-OWNED OR PRIVATE COMPANIES?}

Alibaba leader Jack Ma has set up Luohan Academy, an organisation to promote research on the impact of digital economy. The Academy's 2019report "Digital Technology and Inclusive Growth" (Luohan 2019) well reflects China's position on digitisation. One of the main messages of the report is that digital technology can be an important driver of inclusive growth and the spread of digitalisation and the increase in its efficiency require a close partnership between the public and private sectors. As one of the characteristics of the Chinese economy is the presence of state-owned enterprises (SOEs), it is worth examining the role of these firms - as well as their private counterparts - in the use of R\&D resources and in the digital transformation.

When evaluating MiC25 and other Chinese digitalisation programs, most of the analysts emphasize that the implementation of these programs is not only driven by the will of the state but the private sector is also deeply involved. Moreover, development plans usually designate a specific role to innovative private firms and technology companies.

The indicators of the Global Entrepreneurship and Development Index (GEDI) well illustrate the development of business performance. According to the 2012 GEDI index (based on 20102011 data), China was ranked 58th in the global ranking, between Venezuela and Algeria. Among the pillars summarising institutional and individual variables, it showed the largest lag in the technology sector (Ács - Szerb 2012). This pillar falls into the "Entrepreneurial abilities" (ABT) sub-index of the three sub-indices of the composite GEDI index: these include pillars 
such as the strength of competition (degree of market dominance), the quality of human resources, the importance of the technology sector, and the so-called opportunity-driven business start-ups. The other two sub-indices called "entrepreneurial attitudes" (ATT) and "entrepreneurial aspirations" (ASP) (Komlósi et al. 2014). The 2018 GEDI index (based on 2015-2016 data) already ranks China at 43rd, placing it between Italy and Latvia. The 25 best-performing countries are listed for each sub-index: in 2018, China was already at the forefront of the ASP sub-index (24th place). ASP measures, among other things, the product and process innovation and internationalization capacity of enterprises as well as venture capital financing.

The development of innovative private enterprises is also reflected by the increase in the number and importance of Chinese brands in the world market. Case-by-case examples can illustrate this increase, while indirect data can help to estimate their increasing share of total exports. This is confirmed by the 2019 Fortune Global 500, that lists 119 Chinese companies, including own local brand industries such as computers, telecommunications equipment, industrial equipment, textiles and vehicles, as well as technology and pharmaceutical companies.

Another indicator that is often used to support the claim that the achievements in digital transformation can be traced mainly to the Chinese private companies is the number of Chinese unicorns, i.e. the number of fast-growing Chinese technology companies worth more than 1 billion USD. In May 2020, 472 unicorns were registered in the world (their number is growing month by month). ${ }^{12}$ Most of these companies are American, but the number of Chinese companies has grown at such a rapid rate that China has been second on the list for years (in May 2020, 226 American and 121 Chinese unicorns were on the list). ${ }^{13}$ Funding for these startups has also increased incredibly in recent years in China. In 2017, 48\% of global equity financing for start-up AI businesses was already concentrated in China, while only $38 \%$ to the US. This is a particularly significant increase compared to 2016, when China accounted for only $11 \%$ of global AI funding (Mitchell 2019).

When assessing the role of the corporate sector, one could assume that the mechanisms of economic coordination is purely top-down in the case of China. In reality, Chinese corporate decision-making is characterised by a mixture of top-down statism with a strong bottom-up element, resulting in the simultaneous presence of multiple business systems. The bottom-up elements are provided by the local variations of central institutions - or even informal institutions - which often supersede formal institutions (Witt - Redding 2013), making the whole system more flexible, as successful institutional innovations diffuse across different localities and inform the national level about institutional changes (Xu 2011). Informal relations, that is the so-called guangxi - the network of mutually beneficial relationships which can be used for personal and business purposes - also play a unique role in the Chinese corporate as well as political relationships.

\footnotetext{
${ }^{12}$ The full list is provided by CBInsights: https://www.cbinsights.com/research-unicorn-companies.

${ }^{13}$ With 75 billion USD, Chinese AI company Toutiao is right at the top of the list. Toutiao offers personalised press releases to social media users based on their areas of interest and browsing habits. Didi Chuxing Technology Co. come second on the list with 56 billion USD. The company provides application-based transportation services (taxi service, car, motorcycle and bike sharing, etc.) globally. A total of 19 decacorns - technology companies worth more than 10 billion USD - includes four additional Chinese companies, such as, for example, Bitmain Technologies, which designs application-specific integrated circuit (ASIC) chips for bitcoin mining.
} 
In addition to the often non-competitive and indebted SOEs, there are profit-oriented and competition-driven state-controlled enterprises (such as China Mobile) as well as private firms (Huawei, Lenovo or Geely) that have also been able to become successful in the Chinese market as well as globally. Moreover, such non-state national firms are considered as 'national champions' in China (Naughton 2007; Ten Brink 2013). Apart from the IT sector, that is deeply integrated into global production networks, most industries in China are dominated by national (state-owned, state-controlled or Chinese private) capital and not by foreign multinationals. Chinese firms primarily use domestic funds and bank credit for their operations, partly because major banks are also not privately, but state-owned. As a result, global capital markets play a minor role in funding new investments (Nölke et al. 2015).

The Chinese leadership - and President Xi Jinping personally - identified China's digital strategy as a central concern: the National Informatization Strategy (2016-2020) calls on the Chinese Internet companies to support the creation of a "digital silk road" in foreign markets, while both the MiC25 and the "Internet Plus" program were launched in 2015 to stimulate domestic industrial as well as digital innovation. The relationship between the public and private sectors is truly unique in the field of information and communication technologies (ICT). China's national IT champion companies - such as Baidu, Alibaba, Tencent, Jindong and NetEase - were able to thrive under laboratory conditions because the Chinese leadership not only blocked foreign competitors ${ }^{14}$ but also supported their international expansion and foreign access to capital through listing on overseas stock exchanges.

In the case of state-owned telecommunications giant, ZTE, state paternalism is even more obvious due to direct government funding and preferential procurement. Following the security scandal started in 2018, Huawei is often claimed to be in the same category, but the privatelyowned company denies that it owes its success to government subsidies. Nevertheless, it seems to be almost impossible to trace the influence of the party or the Chinese state, the state control mechanisms and international relations that surround national champion companies - or innovative start-ups (Shi-Kupfer - Ohlberg 2019). What one can conclude with certainty, is, however, that Chinese SOEs will continue to play an important role in developing strategic industries that are directly related either to MiC25 or other digitization programmes. Industries that the Chinese government declares to be a "key industry" (e.g., shipbuilding, aviation, highspeed railways) or a "pillar industry" (e.g., electronics, mechanical engineering, automotive) will continue to be dominated by SOEs. According to MERICS's report (Zenglein - Holzmann 2019: 45), SOEs' share in the revenues of listed companies in these two categories has declined only slightly since 2013 (from 90 to $83 \%$ in "key industries" and from 53 to $45 \%$ in "pillar industries"). However, areas related to other MiC25 priorities - next-generation ICT, robotics,

\footnotetext{
${ }^{14}$ It is indeed difficult for foreign companies to survive in China. When eBay appeared in China in 2002 it quickly gained $70 \%$ market share, however, five years later, its market share fell below 10\%. In 2004, Amazon acquired a Chinese online bookseller, its market share was $15 \%$ in 2008, while now it is below 1\%. In 2005, Microsoft's MSN service entered the Chinese market and gained a 53\% market share among Chinese business users. It decided to leave the market in October 2014, when its share had fallen to less than 5\% due to the competition created by Tencent QQ and WeChat. Uber appeared in China in 2014, spending billions to gain market share from the Chinese competitors. Finally, in 2016, it sold its Chinese subsidiary to a local company. In 2015, Airbnb also arrived in China, but was never able to really compete with the Chinese competitors: in 2017, Airbnb offered 150,000 rooms for rent, while market leader Tujia.com offered 650,000 (Li et al. 2018).
} 
energy-efficient vehicles, new materials, energy equipment, biomedicines, etc. - are mainly dominated by private companies.

\section{MAPPING THE FEATURES OF ADVANCED, KNOWLEDGE-BASED ECONOMIES IN CHINA}

When trying to respond the research question posed at the beginning of the paper - i.e. is the systematic development of emerging industries and technologies suitable to accelerate China's economic growth and achieve the desired shift in its modernisation trajectory - one shall consider some of the features of the more advanced knowledge-based economies (just as the Chinese government technocrats do when creating long-term strategic development plans). These features can be divided into two groups.

The first group includes easy-to-measure indicators, that can easily be used for international economic comparisons, such specialisation in technology/research-intensive or emerging industries, advanced infrastructure, high-tech production equipment, widespread use of state-ofthe-art products and technologies and significant global market share of future-oriented industries. Chinese strategic programs - as well as scientific publications demonstrating their effectiveness (e.g., Song et al. 2017; Zhao 2019) - usually focus on this type of indicators. They refer to the evolution of the share of emerging industries (such as those listed in MiC25) in GDP and exports, China's share of the world market within each "future industry," the number of patents, R\&D spending (and its GDP share), the number of Chinese companies among the world's largest (technology) companies, the number of technology-oriented start-ups, including unicorns, and some further traditional input and output indicators of innovation. ${ }^{15}$ These indicators have been analysed in the previous pages.

In terms of the progress in digital transformation, precisely quantifiable indicators -measuring the spread of technology - are dominant, such as mobile payments and e-commerce, industrial robots, self-driving technology or digital infrastructure. Although I have already expressed doubts about the usefulness of these indicators above, ${ }^{16}$ it has to be reaffirmed that although these indicators do suggest that the Chinese economy is catching up with the more advanced knowledge-based economies in some respects, yet these alone are only superficial results. One can get a more realistic picture on the shift of the modernisation trajectory and on the characteristics of the innovation-driven development when examining the progress that has been made on the specificities of the other group of features of knowledge-based economies. This other group includes difficult-to-quantify factors that are often described only by general terms, however, these characteristics are more closely related with the innovation-driven development trajectory of developed economies than the indicators of the former group. One of these features is that the knowledge required for development and the know-how required for

\footnotetext{
${ }^{15}$ These include, for example, the number of scientific publications, the number of researchers and research institutions and the volume of direct investment in research and development.

${ }^{16}$ This bias is caused, among other things, by the fact that these indicators do not clearly reflect the effectiveness of the shift in modernisation trajectory as there may be large differences in the efficiency of some input indicators, such as R\&D expenditure, and the importance and economic impact of some output indicators, such as patents (see for example, Szalavetz 2011).
} 
operation are mostly created and continuously developed locally (although, of course, they also import knowledge developed elsewhere). This feature of advanced knowledge-based economies can be measured with a variety of indicators; one of these is the decline in the share of foreign value added. The Chinese data are presented in Figure 9, showing a significant decline in the share of foreign value added in Chinese exports in the past one and a half decade.

The progress made in the field of localisation of knowledge can also be measured by the increase in the number and importance of Chinese brands globally. Moreover, this is also reflected in the number of the technology-oriented start-ups and unicorns as well as the number and performance of the fast-growing regional start-up hubs that are constantly launching fastgrowing start-ups specialising in new technology. ${ }^{17}$

Another characteristic of the more advanced economies is that innovation is less concentrated in specific industries, regions and/or specific groups of companies, i.e. not only the large and foreign-owned companies possess it. The number and results of technology-oriented startups and other Chinese achievements in related areas (start-up hubs, venture capital infusion) and the overall improvement in business performance presented above are reflecting not only the localisation of knowledge, but also the spreading of innovation, i.e. the decline in its concentration. These phenomena point to deeper changes than those presented by the more superficial indicators, reflecting the first real results of the shift in the Chinese modernisation trajectory. It has to be added, however, that these are just the first visible signs of the transformation. For instance, Ma and his co-authors (2019) concluded - based on the Chinese databases as well as the data from the balance sheets of the 500 largest listed Chinese companies - that in geographical or regional sense there is no dispersion yet: China's innovation performance is concentrated in the eastern coastal areas, and, as Lu and Cao (2019) pointed out, the development of the key city hubs does not spill over to the surrounding cities. Similarly, the decline in the concentration of industry innovation has just begun: the vast majority of innovations are still connected to high-tech manufacturing and knowledge-intensive services.

A further feature of the more advanced, knowledge-based economies is the significant share of intangible capital in total investments. In order to quantify intangible capital stock, a number of international statistical methodologies have been developed (e.g., Corrado et al. 2005; Ilmakunnas - Piekkola 2014) and econometric calculations have consistently shown a strong and growing role for intangible capital formation among the growth drivers in the developed countries (e.g., Corrado et al.; Fukao et al. 2009). Of course, China has also been involved in the country-level investigations (e.g., Hulten - Hao 2012; Yang et al. 2018; Li - Hou 2019). Their findings suggest that: (1) Although China still lags behind the developed countries, all corporate components of intangible capital, i.e. corporate capital (including company-specific human capital, brand value, business model and market position); IT capital (such as software and other digitized information, databases); and technology capital have grown spectacularly over the past decade; (2) The growth of intangible capital creates a good basis for further productivity development in the long-run, while these investments will not have a strong, direct positive effect on economic growth in the short-run.

\footnotetext{
${ }^{17}$ According to the start-up Genome 2019 report, there are three Silicon Valley-like start-up hubs in China (Beijing, Shanghai and Hong Kong), while Hangzhou and Shenzhen are also on their way to enter the top 30 start-up hubs in the world.
} 


\section{CONCLUSIONS}

Based on the analysis of the literature and statistics detailed above, I found that China has achieved significant results with its economic development strategy based on innovation and digitalisation, named as the digital great leap forward in this article. The (superficial) indicators of the first group reflecting China's economic development have improved remarkably within a short period of time. This is impressive by all means even if most analysts have rightly pointed out that these results could have been achieved more efficiently with a slower pace and/or with fewer resources (Hong et al. 2016; Howell 2017; Wei et al. 2017 - the opposite view is expressed by $\mathrm{Hu}$ - Yongxu 2019). Nevertheless, not just superficial indicators prove that the Chinese economy is moving closer to the more advanced knowledge-based economies: in the past few years, it has become increasingly apparent how extensive efforts are beginning to reap results in intensive development. The localisation and diversification of knowledge has accelerated, the concentration of innovations has decreased, the stock of intangible capital is accumulating and becoming an increasingly significant growth-driver. However, these phenomena only show that China is moving forward on the path to catch-up with the more advanced economies. The road ahead, despite the spectacular results so far, is still long, and closing the gap with the more advanced economies will not necessarily be easier as these countries are also making serious innovation efforts.

I can conclude that the development of the domestic innovation capabilities - based on the large internal market, accompanied by the development of human capital and business incentives - is indeed suitable for transforming the Chinese modernisation trajectory. However, it is not necessarily accelerating China's economic growth. So far, the Chinese economy's performance indicators are determined by traditional drivers (such as infrastructure investment or new export-oriented production capacities) rather than by the new growth drivers. In addition, the shift to a more resource-efficient, higher value-added production will result in significant structural losses, which could adversely affect growth rates.

Is the digital great leap forward - the systematic development of emerging industries and technologies - capable to accelerate China's economic growth and achieve the desired shift in its modernisation trajectory? The answer, in short, is that this strategy and its systematic implementation is essential, but not necessarily sufficient to achieve these goals. China could soon become a high-income economy based on the gross national income per capita levels defined by the World Bank. But for China to become an advanced, knowledge-based economy, further systematic industrial and technology policy efforts are needed, that may take over many decades.

\section{REFERENCES}

Ács, Z. J. - Szerb, L. (2012): Global Entrepreneurship and Development Index, 2012. Cheltenham: Edward Elgar. https://doi.org/10.4337/9781781001158.

Adler, G. - Duval, M. R. A. - Furceri, D. - Sinem, K. - Koloskova, K. - Poplawski-Ribeiro, M. (2017): Gone with the Headwinds: Global Productivity. IMF Staff Discussion Note, No. 17/04. https://doi.org/10.5089/ 9781475589672.006. 
Baily, M. N. - Manyika, J. - Gupta, S. (2013): US Productivity Growth: An Optimistic Perspective. International Productivity Monitor, 25: 3-12.

Bulman, D. - Eden, M. - Nguyen, H. (2014): Transitioning from Low-Income Growth to High-Income Growth - Is There a Middle-Income Trap? Policy Research Working Paper, No. 7104. Washington, DC: World Bank. https://doi.org/10.1596/1813-9450-7104.

Cheng, H. - Jia, J. - Li, D. - Li, H. (2019): The Rise of Robots in China. Journal of Economic Perspectives, 33(2): 71-88. https://doi.org/10.1257/jep.33.2.71.

CISTP (2018): China AI Development Report 2018. China Institute for Science and Technology Policy at Tsinghua University. http://www.sppm.tsinghua.edu.cn/eWebEditor/UploadFile/China_AI_ development_report_2018.pdf.

Corrado, C. A. - Hulten, C. R. - Sichel, D. E. (2005): Measuring Capital and Technology an Expanded Framework. In: Corrado, C. - Haltiwanger, J. - Sichel, D. E. (eds): Measuring Capital in the New Economy. Chicago: University of Chicago Press, pp. 11-46. https://doi.org/10.7208/chicago/ 9780226116174.003.0002.

Corrado, C. - Hulten, C. - Sichel, D. (2009): Intangible Capital and US Economic Growth. Review of Income and Wealth, 55(3): 661-685. https://doi.org/10.1111/j.1475-4991.2009.00343.x.

Dedrick, J. - Kraemer, K. L. - Linden, G. (2010): Who Profits from Innovation in Global Value Chains? A Study of the iPod and Notebook PCs. Industrial and Corporate Change, 19(1): 81-116. https://doi.org/ 10.1093/icc/dtp032.

Dewan, S. (2018): Wired for Work: Exploring the Nexus of Technology \& Jobs. Intergovernmental Group of Twenty-Four and Friedrich Ebert Stiftung, Working Papers, https://www.g24.org/wp-content/ uploads/2018/12/Sabina_Dewan_Wired_for_Work_FINAL.pdf.

Dufrénot, G. - Rhouzlane, M. (2018): Secular Stagnation: New Challenges for the Industrialized Countries in the 21st Century. https://halshs.archives-ouvertes.fr/halshs-01821669/document.

Eichengreen, B. - Park, D. - Shin, K. (2013): Growth Slowdowns Redux: New Evidence on the MiddleIncome Trap. NBER Working Paper, No. 18673. https://doi.org/10.3386/w18673.

Eo, Y. - Morley, J. (2019): Why has the US Economy Stagnated since the Great Recession? The University of Sidney, Economic Working Paper Series, June 2019. https://doi.org/10.2139/ssrn.3077864.

Feenstra, R. C. - Inklaar, R. - Timmer, M. P. (2015): The Next Generation of the Penn World Table. American Economic Review, 105(10): 3150-3182. https://doi.org/10.1257/aer.20130954.

Felipe, J. - Abdon, A. - Kumar, U. (2012): Tracking the Middle-Income Trap: What Is It, Who Is in It, and Why? Levy Economics Institute Working Paper, No. 715. https://doi.org/10.2139/ssrn.2049330.

Fernandes, K. - Goumagias, N. - Shukla, M. - Oxley, G. - Purvis, K. - Cabras, I. - Xiong, Y. - Seddighi, H. - Watson, D. - Coleman, P. - Matthew, S. - Issac, B. - Mary Jacob, S. (2018): "Developing an Innovation Ecosystem: Policy, Skills and Operations", Project Report. North East Local Enterprise Partnership.

Fortune Global 500 (2019): https://fortune.com/global500/2019.

Fukao, K. - Miyagawa, T. - Mukai, K. - Shinoda, Y. - Tonogi, K. (2009): Intangible Investment in Japan: Measurement and Contribution to Economic Growth. Review of Income and Wealth, 55(3): 717-736. https://doi.org/10.1111/j.1475-4991.2009.00345.x.

Glave, L. - Wagner, H. (2019): China in the Middle-Income Trap? China Economic Review, 60: 101264, April 20. https://doi.org/10.1016/j.chieco.2019.01.003.

Gordon, R. J. (2014): The Demise of US Economic Growth: Restatement, Rebuttal, and Reflections. NBER Working Papers, No. 19895. https://doi.org/10.3386/w19895. 
Guillemette, Y. - Turner, D. (2018): The Long View: Scenarios for the World Economy to 2060. OECD Economic Policy Papers, No. 22, Paris. https://doi.org/10.1787/b4f4e03e-en.

Hong, J. - Feng, B. - Wu, Y. - Wang, L. (2016): Do Government Grants Promote Innovation Efficiency in China's High-Tech Industries? Technovation, 57: 4-13. https://doi.org/10.1016/j.technovation.2016.06. 001.

Horowitz, M. C. - Allen, G. C. - Kania, E. B. - Scharre, P. (2018): Strategic Competition in an Era of Artificial Intelligence. Washington: Center for a New American Security (CNAS).

Howell, A. (2017): Picking 'Winners' in China: Do Subsidies Matter for Indigenous Innovation and Firm Productivity? China Economic Review, 44: 154-165. https://doi.org/10.1016/j.chieco.2017.04.005.

Hu, A. G. - Yongxu, D. (2019): Does Government R\&D Stimulate or Crowd Out Firm R\&D Spending? Evidence from Chinese Manufacturing Industries. Economics of Transition and Institutional Change, 27(2): 497-518. https://doi.org/10.1111/ecot.12188.

Hulten, C. R. - Hao, J. X. (2012): The Role of Intangible Capital in the Transformation and Growth of the Chinese Economy. NBER Working Papers, No. 18405. https://doi.org/10.3386/w18405.

Ilmakunnas, P. - Piekkola, H. (2014): Intangible Investment in People and Productivity. Journal of Productivity Analysis, 41(3): 443-456. https://doi.org/10.1007/s11123-013-0348-9.

Jayasooriya, S. P. (2017): Growth Slowdowns, Middle-Income Trap, and Demographic Profile in South Asia. ADBI Working Paper, No. 736.

Jitsuchon, S. (2012): Thailand in a Middle-Income Trap. TDRI Quarterly Review, 27(2): 13-20.

Ketchum, D. - Cheng, S. (2018): Can 'one country, multiple systems' work for China's bay area development?. South China Morning Post February 13. http://www.scmp.com/comment/insight-opinion/ article/2133143/can-one-country-multiple-systems-work-chinas-bay-area.

Komlósi, É. - Szerb, L. - Ács, Z. - Ortega-Argilés, R. (2014): A vállalkozási tevékenység regionális különbségei Magyarországon a regionális vállalkozási és fejlődési index alapján (Regional differences in entrepreneurship in Hungary, based on the regional entrepreneurship index). Közgazdasági Szemle, 61(3): 233-261.

Li, S. - Candelon, F. - Reeves, M. (2018): Lessons from China's Digital Battleground. MIT Sloan Management Review, Summer Issue.

Li, X. - Hou, K. (2019): R\&D Based Knowledge Capital and Future Firm Growth: Evidence from China's Growth Enterprise Market Firms. Economic Modelling, 83(C): 287-298. https://oi.org/10.1016/j. econmod.2019.07.005.

Lin, J. Y. (2019): China's Growth Deceleration: Causes and Future Growth Prospect. Frontiers of Economics in China, 14(1): 26-52.

Lu, Y. - Cao, K. (2019): Spatial Analysis of Big Data Industrial Agglomeration and Development in China. Sustainability, 11(6): 1783. https://doi.org/10.3390/su11061783.

Luohan Academy (2019): Digital Technology and Inclusive Growth. Report 2019, Executive Summary. https://gw.alipayobjects.com/os/antfincdn/DbLN6yXw6H/Luohan_Academy-Report_2019_Executive_ Summary.pdf.

Ma, Z. - Gao, H. - Yin, W. - Wen, Z. (2019): Innovation of Chinese Listed Enterprises: Evaluation and Policies. In: Song, L. - Zhou, Y. - Hurst, L. (eds): The Chinese Economic Transformation. Views from Young Economists. Acton: ANU Press, pp. 143-161. https://doi.org/10.22459/cet.2019.08.

Mitchell, A. (2019): Top 10 Chinese Startups to Watch in 2019. Noteworthy - The Journal Blog, 2019. June 29. https://blog.usejournal.com/top-10-chinese-startups-to-watch-in-2018-90690d7d6109.

Naughton, B. (2007): The Chinese Economy: Transitions and Growth. Cambridge: MIT Press. 
Nölke, A. - Ten Brink, T. - Claar, S. - May, C. (2015): Domestic Structures, Foreign Economic Policies and Global Economic Order: Implications from the Rise of Large Emerging Economies. European Journal of International Relations, 21(3): 538-567. https://doi.org/10.1177/1354066114553682.

OECD (2019a): OECD Compendium of Productivity Indicators. Paris. https://doi.org/10.1787/b2774ff7-en. OECD (2019b): OECD Economic Surveys: China. Paris. https://doi.org/10.1787/eco_surveys-chn-2019-en. Remes, J. - Mischke, J. - Krishnan, M. (2018): Solving the Productivity Puzzle: The Role of Demand and the Promise of Digitization. http://www.csls.ca/ipm/35/Remes-Mischke-Krishnan.pdf.

Shi-Kupfer, K. - Ohlberg, M. (2019): China's Digital Rise - Challenges for Europe. MERICS Papers on China, No. 7, April 2019.

Song, L. - Garnaut, R. - Fang, C.- Johnston, L. (eds): (2017): China's New Sources of Economic Growth: Vol. 2: Human Capital, Innovation and Technological Change. Acton Australia: ANU Press. https://doi.org/ 10.22459/cnseg.07.2017.

Startup Genome (2019): Global Startup Ecosystem Report 2019. www.startupgenome.com.

Syverson, C. (2017): Challenges to Mismeasurement Explanations for the US Productivity Slowdown. Journal of Economic Perspectives, 31(2): 165-186. https://doi.org/10.1257/jep.31.2.165.

Szalavetz, A. (2011): Innovációvezérelt növekedés? (Innovation-driven growth?). Közgazdasági Szemle, 58(5): 460-476.

Szalavetz, A. (2017): Industry 4.0 in 'Factory Economies'. In: Galgóczi, B. - Drahokoupil, J. (ed.): Condemned to be Left Behind. Can Central and Eastern Europe Emerge from its Low-Wage Model? Brussels: ETUI, European Trade Union Institute, pp. 133-152.

Szalavetz, A. (2019): Mesterséges intelligencia és technológiavezérelt termelékenységemelkedés (Artificial intelligence and technology-driven productivity growth). Külgazdaság, 63(7-8): 53-79.

Ten Brink, T. (2013): Chinas Kapitalismus. Entstehung, Verlauf, Paradoxien/China's Capitalism: Emergence, Trajectory, Paradoxes. Frankfurt and New York: Campus.

Tho, T. V. (2013): The Middle-Income Trap: Issues for Members of the Association of Southeast Asian Nations. ADB Working Paper, No. 421. Manila: Asian Development Bank. https://doi.org/10.2139/ssrn. 2266239.

Tian, G. (2019): Deceleration of China's Economic Growth: Causes and Countermeasures. Frontiers of Economics in China, 14(1): 3-25.

Wei, S. J. - Xie, Z. - Zhang, X. (2017): China's Transition to a More Innovative Economy. Progress and Challenges. In: Song, L. - Garnaut, R. - Fang, C. - Johnston, L. (eds): China's New Sources of Economic Growth, Vol. 2, Human Capital, Innovation and Technological Change. Australian National University Press and Social Sciences Academic Press (China), pp. 173-211. https://doi.org/10.22459/cnseg.07.2017. 08.

Witt, M.A. - Redding, G. (2013): Asian Business Systems: Institutional Comparison, Clusters and Implications for Varieties of Capitalism and Business Systems Theory. Socio-Economic Review 11(2): 265300 .

Woo, W. T. (2017): Adjusting to the New Domestic Normal and the New International Normal: Supplyside Structural Reform 2.0. In: Song, L. - Garnaut, R. - Fang, C. - Johnston, L. (eds): China's New Sources of Economic Growth, Vol. 2, Human Capital, Innovation and Technological Change. Australian National University Press and Social Sciences Academic Press (China). https://doi.org/10.22459/cnseg. 07.2017.05.

Xiong, A. - Xia, S. - Ye, Z. P. - Cao, D. - Jing, Y. - Li, H. (2020): Can Innovation Really Bring Economic Growth? The Role of Social Filter in China. Structural Change and Economic Dynamics, 53: 50-61. 
Xu, C. (2011): The Fundamental Institutions of China's Reforms and Development. Journal of Economic Literature, 49: 1076-1151.

Xu, X. (2019): The Slowdown of China's Economic Growth in Terms of Statistics. Frontiers of Economics in China, 14(1): 72-79.

Yang, S. - Zhou, Y. - Song, L. (2018): Determinants of Intangible Investment and Its Impacts on Firms' Productivity: Evidence from Chinese Private Manufacturing Firms. China \& World Economy, 26(6): $1-26$.

Zenglein, M. J. - Holzmann, A. (2019): Evolving Made in China 2025 - China’s Industrial Policy in the Quest for Global Tech LeadershipMERICS. Papers on China, No. 8, July

Zhao, W. (2019): China's Innovation-Driven Growth and its Emerging Impact on Global Innovation. In: Wang, H. - Miao, L. (eds): Handbook on China and Globalization. Cheltenham: Edward Elgar, pp. 175-185. https://doi.org/10.4337/9781785366086.00018.

Zhuang, J. - Vandenberg, P. - Huang, Y. (2012): Growing Beyond the Low-Cost Advantage: How the People's Republic of China can Avoid the Middle-Income Trap. Manila: Asian Development Bank.

Open Access. This is an open-access article distributed under the terms of the Creative Commons Attribution 4.0 International License (https://creativecommons.org/licenses/by/4.0), which permits unrestricted use, distribution, and reproduction in any medium, provided the original author and source are credited, a link to the CC License is provided, and changes - if any - are indicated. (SID_1) 